\title{
MANAGEMENT OF THE SURABAYA SYARIAH NAMIRA HOTEL IN PERSPECTIVE OF SHARIA HOTEL PRINCIPLES AND REGULATION OF THE MINISTER OF TOURISM AND CREATIVE ECONOMY OF THE REPUBLIC OF INDONESIA NUMBER 2 OF 2014
}

\author{
Ubaid Aisyul Hana \\ IKHAC Pacet Mojokerto \\ alhanaubaid@gmail.com
}

\begin{abstract}
This research is a field research to highlight service of the Surabaya Syariah Namira Hotel in the perspective of sharia hotel principles and Regulation of the Minister of Tourism and Creative Economy of the Republic of Indonesia Number 2 of 2014. To elaborate on that theme, there are two core issues that will be answered, namely: how is the management of the Surabaya Syariah Namira Hotel? And how is the management of the Surabaya Syariah Namira Hotel in the perspective of Sharia principles and the Regulation of the Minister of Tourism and Creative Economy of the Republic of Indonesia Number 2 of 2014? The data obtained through observation, interview and documentation. The results showed that the service and management of the Surabaya Syariah Namira Hotel is carried out in accordance with the internal hotel regulations and completed with facilities as required in sharia hotel. While based on sharia principles and the Regulation of the Minister of Tourism and Creative Economy of the Republic of Indonesia Number 2 of 2014, the Surabaya Syariah Namira Hotel is adequate to be classified as sharia hotel and as the Hilāl-1 category.
\end{abstract}

Keywords: Surabaya Syariah Namira Hotel, servive, management

\begin{abstract}
Abstrak: Penelitian ini merupakan penelitian lapangan untuk menyoroti pelayanan Hotel Syariah Namira Surabaya dalam perspektif prinsip hotel syariah dan Peraturan Menteri Pariwisata dan Ekonomi Kreatif Republik Indonesia Nomor 2 Tahun 2014. Untuk mengelaborasi tema tersebut, ada dua inti permasalahan yang akan dijawab yaitu: bagaimana pengelolaan Hotel Namira Syariah Surabaya? Dan bagaimana pengelolaan Hotel Surabaya Syariah Namira dalam perspektif prinsip Syariah dan Peraturan Menteri Pariwisata dan Ekonomi Kreatif Republik Indonesia Nomor 2 Tahun 2014? Data diperoleh melalui observasi, wawancara dan dokumentasi. Hasil penelitian menunjukkan bahwa pelayanan dan pengelolaan Hotel Surabaya Syariah Namira dilakukan sesuai dengan peraturan internal hotel dan dilengkapi dengan fasilitas yang sesuai dengan kebutuhan di hotel syariah. Sedangkan berdasarkan prinsip syariah dan Peraturan Menteri Pariwisata dan Ekonomi Kreatif Republik Indonesia Nomor 2 Tahun 2014, Hotel Surabaya Syariah Namira sudah layak diklasifikasikan sebagai hotel syariah.
\end{abstract}

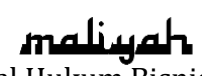

Jurnal Hukum Bisnis Islam

Volume 11, Nomor 01, Juni 2021

p-ISSN: 2088-4869/ e-ISSN: 2597-4351 
Kata Kunci: Hotel Surabaya Syariah Namira, pelayanan, manajemen

\section{Introduction}

In line with the increasingly widespread Islamic financial, business, product, and tourism institutions in Indonesia, many institutions apply sharia principles in conducting their business. One of which is a Sharia hotel. The Sharia hotel business is currently increasing and is increasingly in demand by visitors with different goals and reasons in expressing why choosing sharia hotel. Because Indonesia is a country with the largest Muslim population, there can be opportunities with the establishment of Islamic hotels that hold Islamic principles. ${ }^{1}$

Departing from the increasingly rampant Sharia hotel business, the Ministry of Tourism and Creative Economy in collaboration with the National Sharia Council-Indonesian Ulema Council drafted Minister of Tourism and Creative Economy Regulation No. 2 of 2014 concerning guidelines for sharia Hotel Operations which began enacted on January 17, 2014. Sharia Hotel is a hotel which, in its implementation process, always uses sharia principles. The sharia hotel also meets the absolute criteria applicable to the sharia hotel business, which includes product, service, and management.

In the aspect of product, Phlip Kotler said that products are everything that can be offered to the market to satisfy a desire or need, including physical goods, services, experiences, events, people, places, property, organizations and ideas. ${ }^{2}$ In planning its market offerings, Sharia hotels must see the benefits of the products they offer in order to add greater customer value. Hotel's consumers in choosing a place to stay have a variety of criteria. In this case, the management is required to always try to improve services and innovate continuously.

In addition, service aspects in several management charts can be found in several definitions of service concepts. US. Moenir stated that the process of meeting needs through other

\footnotetext{
${ }^{1}$ Rambat Lupiyadi, Manajemen Pemasaran Jasa (Salemba: Jakarta, 2008), 6.

2 Phlip Kotler, Manajemen Pemasaran (Jakarta: PT. Gelora Aksara Pratama, 2009), 4.
}

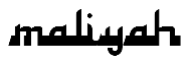


people's direct activities is called service. So it can be said that service is an activity that aims to help preparing or taking care of what others need. ${ }^{3}$ Fandy Tjiptono in his book "Service Management" considers service as an intangible product that results more in the form of activity than physical objects, despite the fact that physical products are involved (for example, food and drinks in restaurants). So, in this case, the scope is the product offer. Service can also be seen as a system that consists of two main components, namely service operations that are often invisible or unknown to the customer (back office or backstage) and service delivery that is usually visible or known to customers (front office or frontstage). ${ }^{4}$

Next is the management aspect. Concerning with this, every business must have good management so that the company can operate as desired without any obstacles and to maintain the product they have. Basically, management is the control and utilization of all resources according to a plan needed to complete a particular goal. Irawan defines management as management, namely the mobilization, organization and direction of human efforts to effectively utilize materials and facilities to achieve certain goals. ${ }^{5}$.

The Surabaya Syariah Namira Hotel exists in the midst of the community to compete with other hotels by not only labeled sharia but also in its operations based on sharia. The Surabaya Syariah Namira Hotel, located on south of the Great Mosque of Surabaya, determines an affordable price according to the economy of the wider community. The Surabaya Syariah Namira Hotel is still classified as a 3 Star Hotel. The services provided by the receptionist are also inseparable from sharia values such as greetings when guests enter, not providing

\footnotetext{
3 Moenir, Maanajemen Pelayanan Umum di Indonesia (Jakarta: PT. Bumi Aksara, 2002), 16

4 Fandy Tjiptono, Service Manajemen: Mewujudkan Pelayanan Prima (Yogyakarta: ANDI, 2008), 2

${ }^{5}$ Rizka Saputri, "Tinjauan Hukum Islam Tentang Praktek Pengelolaan Hotel Syariah (Studi di G Hotel Syariah di Lampung)" (undergraduate thesis-UIN Raden Intan, Lampung, 2017), 22.
}

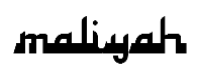

Jurnal Hukum Bisnis Islam 
alcoholic drinks, there is a tap for wudhu (ablution), qibla direction and al-Qur'an in the room, and so forth.

Being the second largest city in Indonesia, Surabaya is a city that combines elements of business and tourism which certainly makes accommodation one of the elements that are always needed. Hotel competition in big cities is very tight, like Surabaya for example, because in addition to cities that have visited tourist attractions, the term as a metropolitan city has its own meaning. The high number of visitors results in high demand for lodging with various rates according to the ability of consumers.

Seeing this, the Surabaya Syariah Namira Hotel is coming to complement those needs by combining the concepts of beauty, cleanliness and Islamic nuance. Namira Syariah Hotel Surabaya is ready to serve the needs of guests who will stay a while in Surabaya. The Surabaya Syariah Namira Hotel relies on the concept of sharia by targeting worshipers and visitors to the AlAkbar Great Mosque in Surabaya. Fadli said, the average visitors who visit the Al-Akbar Great Mosque reach 30,000 to 40,000 people per day. Whereas, on Friday, it can reach 50,000 or even when there is wedding event, it can reach more than that. ${ }^{6}$

The hotel owner, Mustofa Bawazieer, added that his party deliberately choses the sharia hotel, because the location is close to a large mosque. "The concept of sharia, according to location, is also for the convenience of guests. We treat male and female guests with non-muhrim in different rooms. And it can be known through guests' identity card with the same address." 7 One of the reception staff said that for the restaurant, Al-Arush, also confirmed its sharia, using halāl raw materials in its processing. Because the restaurant provides

\footnotetext{
${ }^{6}$ Issued in http://surabaya.tribunnews.com/2017/07/30/andalkan-konsep-syariahhotel-namira-syariah-bidik-jemaah-dan-pengunjung-masjid-al-akbar, 25 Januari 2018.

${ }^{7}$ Mustofa Bawazieer, Interview, Surabaya 20 January 2018
}

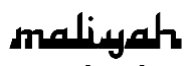


Indonesian, Middle Eastern, slightly European and Asian foods. ${ }^{8}$

Unfortunately, even though it has implemented a selection for guests who want to stay, the Surabaya Syariah Namira Hotel still has to apply other sharia principles in each of its business activities. On the other hand, the Surabaya Syariah Namira Hotel has not been officially registered on the East Java Creative Economy and Tourism Office as a hotel with a sharia concept and has not yet received a certificate to run a sharia hotel business. It is because based on Minister of Tourism and Creative Economy Regulation No. 2 of 2014 Article 11, that only hotel entrepreneurs who have obtained certificates of sharia hotel business issued by DSN-MUI can postulate themselves as sharia hotels.

The sharia hotel entrepreneurs who have obtained certificates and found deficiencies are obliged to correct the shortcomings that exist within a maximum period of six months from the fact that the shortage is first known. If after the six-month period as referred to by the sharia hotel businessman cannot correct the shortcomings, the hotel concerned is prohibited from conducting sharia hotel business and is prohibited from postulating himself as a sharia hotel business.

With these considerations, the researcher would like to further examine the application of sharia principles in the Surabaya Syariah Namira Hotel in terms of Sharia principles and the Minister of Tourism and Creative Economy Regulation of the Republic of Indonesia Number 2 of 2014 concerning guidelines for sharia hotel business operations.

\section{Concept and Development of Conventional Hotels in Indonesia}

Hotel is one of business sectors that is currently in great demand by capital owners. Aside from being a hobby, the hotel business also promises a pretty fantastic income. Sutanto

\footnotetext{
${ }^{8}$ Enny, Interview, Surabaya 21 January 2018
} 
defines the hotel is a company managed by the owner, by providing food, drink and room facilities for sleeping to people who travel and can pay a reasonable amount in accordance with the services received without any special agreement. ${ }^{9} \mathrm{~A}$ hotel is also a type of accommodation that uses part or all of a building to provide commercially managed lodging, food and beverage services and meets the conditions set by the government. ${ }^{10}$

In principle, hotel is a form of business engaged in services for hotel guests both physically, psychologically and security as long as guests use the facilities or enjoy services at the hotel. ${ }^{11}$ From the above understanding, it can be concluded that: (1) hotel is a type of accommodation that uses part or all of the existing building; (2) hotel provides service facilities in the form of lodging, food and beverage services, and other services; (3) hotel is a service facility that is open to the public on a trip; (4) hotel is a commercially managed business.

Still related to the definition and function of hotel in the realm of economic development, the hotel also provides information to guests who will stay at the hotel about the standards and facilities owned by each and type of hotel, so Sugiato classifies hotels based on the intended use during their stay, i.e.: (1) business hotel, which is used by entrepreneurs for business; (2) recreational hotels, namely hotels that are made for people to relax and in recreation. ${ }^{12}$

Whereas, based on location, hotel is divided into: (1) city hotel, which is located in the city and most of the guests who stay overnight do business activities; (2) resort hotel, which is located in a tourist area and most of the guests staying are not doing business. Various resort hotels based on their location are: mountain hotel (hotel in the mountains), beach hotel (hotel

\footnotetext{
9 Sutanto, Hotel Proprietors Act dalam Manajemen Penyelenggara Hotel, (Jakarta: Salemba, 2005), 5.

${ }^{10}$ Ibid., 6.

${ }^{11}$ Agus Nawar, Psikologi Pelayanan (Bandung: Alfabeta, 2002), 54.

12 Sugianto, Hotel Front Office Administration, Administrasi Depan Office (Jakarta: Gramedia Pustaka Utama, 2000), 85.
}

\section{malinath}


on the beach), lake hotel (hotel in the lake area), hill hotel (hotel on the hilltop), forest hotel (hotel in the area protected forest), suburb hotel, is a hotel located on the outskirts of the city and as a meeting between two municipalities.

Based on the type and purpose of the hotel, Sugiato classifies hotels based on the intended use during their stay, namely: (1) business hotel, which is used by business people for business; (2) recreational hotels, namely hotels that are made for people to relax and be in recreation. ${ }^{13}$ Hotel classifications are distinguished by using a star symbol between 1-5. The more stars a hotel has, the more qualified the hotel is. Based on the Decree of the Director General of Tourism Number 14/U/II/1988, hotel business and management explain that the classification of hotels uses a star system. From the lowest class given one star up to the highest class is a fivestar hotel. Whereas hotels that do not meet the standards of the fifth class or that are below the specified minimum standards are called non-star hotels. ${ }^{14}$

\section{Concept and Development of Sharia Hotel in Indonesia}

In line with the rise of the conventional hotel business in Indonesia, the sharia hotel business is also experiencing rapid development. Subsidiary, sharia hotel is a hotel where the supply, procurement and use of products and facilities and their operations does not violate sharia rules. All components of the hotel operational technical criteria, ranging from small things such as what information must be available at the front office, toilets, to the presentation of the types of food and drinks available at reception policies and procedures, houserules must be ensured all meet shariah criteria.

Succinctly, the business signs in sharia hotel can be described as follows: (1) not producing, trading, providing, renting a product or service which, in whole or in part, is prohibited or not recommended in sharia, such as foods

13 Sugianto, Hotel Front Office Administration, Administrasi Depan Office (Jakarta: Gramedia Pustaka Utama, 2000), 85.

${ }^{14}$ Keputusan Dirjen Pariwisata Nomor 14/U/II/1988. 
containing elements of pork, alcoholic beverages or intoxicants, gambling, adultery, pornography, porno-action and others; (2) the transaction must be based on a real service or product; (3) there is no tyranny, destruction, damage, disobedience, error and involvement, either directly or indirectly in an action or thing that is prohibited or not recommended by sharia; (4) there is no element of cheating, lying, vagueness (gharar/uncertain), excessive risk, corruption, manipulation, and getting an outcome without willing to participate in business or bear the risk; (5) overall commitment to the agreement made. ${ }^{15}$

From the sharia hotel business guidelines above, the hotel operations are aligned. After knowing the side of the hotel operations then made the standards or criteria for Islamic hotels as follows: First, facilities. All facilities, both basic facilities that must be owned by the hotel and additional facilities, will provide positive benefits for guests. As for facilities that can have an impact on damage, division, arouse lust, exploitation of women and others of the same type are eliminated, and entertainment facilities for procurement refer to sharia principles.

Adjustment of hotel's products and facilities are in accordance with sharia by removing and closing products and facilities that are not sharia compliant (such as night clubs, discos, bars with alcoholic drinks) and replaced with similar forms in accordance with sharia. Neutral facilities (such as swimming pools, fitness centers, massages) are only regulated so that their use does not violate sharia. The use of the facilities provided is also adjusted to the purpose of holding them so that there is no misuse of the facility or irregularities in the use of the facility.

Second is guest. Guests who check-in, especially for opposite-sex couples, do a guest selection (reception policy). Couples are husband and wife or not to prevent the hotel from being used for adultery. Third is marketing. Open to anyone,

${ }^{15}$ Riyanto Sofyan, Bisnis Syariah Mengapa Tidak? (Jakarta: Gramedia Pustaka Utama, 2011), 64-65.

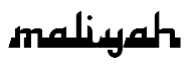


personal or group, formal or informal with various ethnic, religious, racial and group. As for the groups' activities are not prohibited by the state and do not constitute advocates of damage, violation, and hostility as well as other similar acts.

Fourth is food and beverage. Food and drink provided is those which are not prohibited by sharia (haläl). In making food and drinks, both the ingredients and the production process must be guaranteed halāl (not mixed with ingredients that are prohibited by sharia). The restaurant is open at any time as well as in the month of Ramadan for people who travel long distances (safär), women who are unable to fast and people who have legal difficulties by not reducing respect for those who fast. 16

Fifth is decoration and ornament. Decoration and ornaments are adjusted to the values of beauty in Islam and do not conflict with sharia. Sculpture ornaments are eliminated as well as paintings of living things also avoided. Even so, hotel decor does not have to be in the form of calligraphy or other Middle Eastern nuances. ${ }^{17}$ Sixth is operational. Inward company policies in the form of management policies and regulations that are made must be in accordance with sharia values. Likewise, the exit policy either in the form of cooperation or investment and business development is carried out with partners whose business activities are not prohibited from sharia and for businesses that are not prohibited from sharia. ${ }^{18}$

Seventh are human resources. Admission and recruitment do not differentiate between ethnicity, religion, as long as they meet predetermined qualification standards, are moral and able to comply with applicable company rules. Companies must be honest with employees in giving up their rights and employees must be honest and trustworthy in carrying out

\footnotetext{
${ }^{16}$ Fadhlan Mudhafier, Makanan Halal (Jakarta: Zakia Press, 2004), 37.

17 Riyanto Sofyan, Bisnis Syariah Mengapa Tidak? Penerapan pada Bisnis Hotel, (Jakarta: PT. Gramedia Pustaka, 2011), 71.

18 Didin Hafidhuddin, Hendri Tanjung, Manajemen Syariah dalam Praktik (Jakarta: Gema Insani Press, 2003), 33
} 
their obligations. Eighth is finance. Financial management is adjusted to the financial management system according to Islamic law (sharia accounting). Partnerships with financial institutions such as banks and insurance are carried out with financial institutions and Islamic insurance. If the entrepreneur has a sufficient profit in the amount of zakat, the company is obliged to issue zakat. ${ }^{19}$

Ninth is structure. The existence of an institution that oversees the operation of sharia hotels and which provides direction and answers problems that may arise in the field relating to the implementation of sharia hotel operations. This institution is the sharia supervisory board. People who sit in it are those with sharia education background who have knowledge of the rules of Islamic law. ${ }^{20}$

Tenth is service. The services provided should be according to the Islamic method which meets aspects of hospitality, friendliness, honesty, trustworthy, like to help and say the word sorry and thank you. Services must also be carried out within the limits permitted by the sharia, that is not lead to khalwat (mixing of men and women who are not in accordance with sharia principles).

Eleventh is facilities. Worship in hotels must be equipped with a mosque or prayer room that is comfortable and representative. The call to prayer should be echoed at every prayer time, mounted speakers to continue the call to prayer on every corner or floor of the hotel. Each hotel room is facilitated with worship equipment such as mukena and sarong, prayer mats, al-Qur'an, clearly defined direction of qibla, and Islamic decoration.

\section{Minister of Tourism and Creative Economy Regulation No. 2 of 2014}

Minister of Tourism and Creative Economy Regulation Number 2 of 2014 concerning guidelines for sharia hotel

19 M. Rayhan Janitra, Hotel Syariah Konsep dan Penerapan (Depok: Raja Grafindo Persada, 2003), 35.

${ }^{20}$ Ibid., 40.

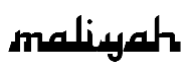


business administration makes 2 categories, namely Hilāl-1 and Hilāl-2 and 2 criteria, namely absolute criteria in the certification process of sharia hotel business. Sharia hotel business certification is the process of awarding certificates to hotel businesses through audits to assess the suitability of products, services and hotel business management with the criteria of sharia hotel business.

The following is an explanation of the Hilāl-1 and Hilāl-2 categories and the absolute criteria according to article 1 point $5,6,7,8$ Regulation of the Minister of Tourism and Creative Economy Number 2 of 2014: (a) Hilāl-1 sharia hotel is a classification for a sharia hotel business that is considered to meet all the criteria of a sharia business hotel that is needed to serve the minimum needs of Muslim tourists; (b) Hilāl-2 sharia hotel is a classification for a sharia hotel business that is judged to meet all sharia hotel business criteria needed to serve the moderate needs of Muslim tourists; (c) Absolute criteria are the minimum terms and conditions regarding products, services, and management that must be met and implemented by a hotel entrepreneur so that they can be recognized as a sharia hotel business and obtain a sharia hotel business certificate; (d) Absolute criteria are the provisions and requirements regarding products, services and management that can be implemented by sharia hotel entrepreneurs, in order to meet the particular needs of Muslim tourists.

In addition, sharia hotel is a hotel that operate its products, services and management based on principles or do not violate sharia rules. Fatwa of the National Sharia Council-Indonesian Ulema Council Number 108 of 2016 concerning guidelines for the implementation of tourism based on sharia principles. The provisions related to sharia hotels are namely: (a) Sharia hotels may not provide access to pornography or immoral acts; (b) Sharia hotels may not provide entertainment facilities that lead to immoral polytheism, ponography and/or immoral acts; (c) Food and beverages provided by the hotel must have obtained halāl certificate from Indonesian Ulema Council (MUI); (d) Providing adequate facilities, equipment and facilities for the performance of worship, including cleaning facilities; (e) Hotel

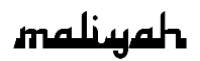


management and employees/employees are required to wear clothing that is in accordance with sharia; (f) Sharia hotels are required to have guidelines and/or guidelines regarding hotel service procedures to ensure the implementation of hotel services in accordance with sharia principles; (g) Sharia hotels are obliged to use the services of Islamic financial institutions in conducting services.

\section{The Surabaya Syariah Namira Hotel: from Profile to Management}

The Surabaya Syariah Namira Hotel is one of the hotels with Islamic nuance that prioritizes the concept of sharia and halāl with the standard of 3-star hotel. The Surabaya Syariah Namira Hotel was established in 2017 and was inaugurated on July 29, 2017 under the management of PT. Griya Lestari Hotel and the shade of Harmoni Imara Management. The Surabaya Syariah Namira Hotel is a subsidiary of the Syariah Namira Hotel in Pekalongan, which has the same standards and concepts as the Surabaya branch. ${ }^{21}$

Syariah Namira Hotel was established in Surabaya. It is because Surabaya is a city that combines elements of business and tourism which certainly makes accommodation an element that is always needed. Hotel competition in big cities is very tight, like Surabaya for example, because in addition to cities that have visited tourist attractions, the term as a metropolitan city has its own meaning. The high number of visitors results in high demand for lodging with various rates according to the ability of consumers.

The Surabaya Syariah Namira Hotel currently has 71 guest rooms with 4 types of rooms, namely Superior, Deluxe, Executive, Suite. In addition to guest rooms, the Surabaya Syariah Namira Hotel also provides a Meeting Room with 3 types of rooms, namely Dubai, Abudhabi, Sarjah, and Al-Arush and Gahwaji Sky Lounge restaurants. In addition, Syariah Namira Hotel is the only sharia hotel located in South Surabaya.

${ }^{21}$ Issued in Company Profile of the Surabaya Syariah Namira Hotel, March 16, 2018 . 
The closest landmarks to the Syariah Namira Hotel Surabaya are the Surabaya Al-Akbar Mosque with a distance of $150 \mathrm{~m}$, City of Tomorrow Mall is $1.7 \mathrm{~km}$, Surabaya Carnival is $2.1 \mathrm{~km}$, Sunan Ampel State Islamic University is $1.5 \mathrm{~km}$, and Petra Christian University is $2.4 \mathrm{~km}$, Royal Plaza is $3.8 \mathrm{~km} .{ }^{22}$

Reservation of the Surabaya Syariah Namira Hotel rooms can be done directly in the hotel lobby or by telephone. For bookings made by telephone, hotel management sets a deposit rule in advance for a minimum of one night of the room type to be booked for booking certainty. When booking is done directly, payment can be made at the same time to the hotel front office employee. ${ }^{23}$

The role of check-in at the Surabaya Syariah Namira Hotel is starting at 14:00 West Indonesia Time (WIT) and check-out at 12.00 WIT the next day. For late check out until 3:00 p.m. WIT, hotel management charges an additional rate of $25 \%$ from the normal room rate booked by guests. If the delay is above 15.00 hours, an additional rate of $50 \%$ will be charged from the normal rate and if the delay is above 17.00 WIT, the hotel management will provide a full charge. ${ }^{24}$

To maintain security, order and maintain the nuances of Islam in the hotel environment, the manager of the Syariah Namira Hotel management applies several rules as follows:

1. Each hotel guest must carry a valid identity card (KTP/SIM/Passport) (with the same address).

2. Paying the price of the room every day. Start checking in at 14:00 WIT and check out 12:00 WIT.

3. Not allowed: to bring women/couples who are not his or her own family, to commit immoral acts, to carry sharp weapons and the like, to carry and consume liquor, drugs and the like, to bring pets, to make noise/disturb the comfort in the hotel.

4. All facilities bookings are paid directly on the same day.

\footnotetext{
${ }^{22}$ Issued in https://www.booking.com/hotel/id/namira-syariah-surabaya.id.html

${ }^{23}$ Puspa, Interview, Surabaya 20 January 2018.

${ }^{24}$ Rifa, Interview, Surabaya 21 January 2018.
} 
5. Guests must take responsibility if they damage/eliminate hotel property.

6. Comply with check-in and check-out deadlines that apply at the hotel.

7. If the guest does not complete the room administration for up to 2 days, the hotel has the right to force to check out and spend

8. It is forbidden to sound music and play any kind of instrument in all areas of the hotel, and if it turns out that in actual conditions there is music or playing an instrument, we have the right to stop unilaterally

\section{Analysis of Sharia Concepts on Management of Syariah}

As an industry engaged in services/tourism, the Surabaya Syariah Namira Hotel must pay attention to guests who stay with good service based on sharia principles. One of the factors that can attract the attention of guests is the management of products and services available at Syariah Namira Hotel. In general, guests will always remember what has been presented to the guest. If the guests get satisfaction from what is presented, then they will feel reluctant to turn to other competitors. ${ }^{25}$

In the hospitality business, a management of products and services is also needed to see the demand from different markets. As with guest services that come with families is different from guests who come only husband and wife in the context of honey moon. Likewise, the traders or tourism who stop by to unwind. Another case for Muslim guests who definitely need lodging with good service with Islamic principles, this will be their main consideration. Therefore, sharia hotels appear to provide services to Muslim guests in accordance with sharia principles. This hotel will become the ideal sharia hotel for guests who are Muslim.

By applying the principles of sharia, the Surabaya Syariah Namira Hotel can conduct business according to sharia

${ }^{25}$ Abdul Mujib, "Analisis terhadap Konsep Syariah pada Industri Perhotelan di Indonesia”, Jurnal Ilmu Syariah dan Hukum, Vol. 50. No. 2. 
accordingly through products, services and management that can provide benefits from various aspects both in the world and the hereafter. According to Khalda, that the implementation of sharia values have been done periodically by hotel management since the establishment of the hotel to get a certificate from Indonesian Ulema Council (MUI), but until now the certificate has not been given to us, the process is indeed long, especially since this Syariah Namira Hotel is still relatively new, established in 2017.26

Sharia Values in the Syariah Namira Hotel are subject to regulations issued by the Ministry of Tourism and Creative Economy Number 2 of 2014 concerning guidelines for sharia business operation. This regulation covers several aspects in conducting sharia hotel business, evaluation in the context of sharia hotel business certification, and guidance as well as supervision. As a form of commitment to serve guests, the Surabaya Syariah Namira Hotel has compiled several key elements of service ranging from product, service and management aspects.

The Shariah criteria of hotel, especially the Surabaya Syariah Namira Hotel in the government regulations is basically the same. The important point of the arrangements made is how to conditionate the diversity of guests who stay at each hotel. The provision of sharia services in each hotel is aimed at tourists or Muslim guests. In other words, sharia in the above conception is more an effort to provide support in increasing faith and devotion.

Viewed from the market orientation, both in the government regulations and from the experience of applying sharia in the Surabaya Syariah Namira Hotel, it tends to be directed towards the Muslim market. The description of this orientation is very easy to capture from several points that become the criteria of the existing arrangements, for example from the in-room facilities. Each room is given mushaf and

${ }^{26}$ Khalda, Interview, Surabaya 20 January 2018. 
prayer rugs and also equipped with calligraphy and other Islamic symbols.

Another thing that is the most important part of the criteria for sharia at the Syariah Namira Hotel is the separation of male and female guests, especially those who are not Muslim. In the context of services like this, Syariah Namira Hotel strives to build a positive image and eliminate the negative impression of all services provided in the hotel. This arrangement is also informed in writing and orally to guests who will make the reservation and check-in process.

The criteria for sharia are quite interesting when entering into the area of organization and management. Because the emphasis of sharia must start from management of human resources before entering the guest. In the sharia hotel organizational structure, a Sharia Supervisory Board (DPS) is required. In this context, the presence of DPS is an important point to control all sharia hotel products, services and management in order to stay within sharia standards.

The implementation of the sharia concept at Syariah Namira Hotel is still in the stage of adjusting itself to the existing regulations, namely Tourism and Creative Economy Number 2 of 2014 concerning guidelines for sharia business operations. The adjustment was made since the establishment of the hotel in the hope that it would have readiness starting from products, services, and management in the certification process carried out by Indonesian Ulema Council (MUI) to obtain certificates.

In connection with the above matters, many comments from guests who in essence are still at the stage of adjustment in operations including products, services and management. For the application of sharia in the Syariah Namira Hotel is included in the good category because what is felt by the guests is the values contained in the Syariah Namira Hotel Surabaya.

Analysis of Management of the Surabaya Syariah Namira Hotel in Perspective of Regulation of the Minister of Tourism and Creative Economy of the Republic of Indonesia Number 2 of 2014 
The Surabaya Syariah Namira Hotel does not yet have a sharia hotel business certificate issued by the National Sharia Council of the Indonesian Ulema Council (DSN-MUI). The certification is a requirement for hotels to post themselves as sharia hotel business in accordance with the Minister of Tourism and Creative Economy Regulation No. 2 of 2014 concerning guidelines for sharia business hotel operations in Indonesia. The government sets regulations with two new hilāl categories that can be applied in sharia hotels throughout Indonesia, namely the Hilāl-1 and the Hilāl-2 category.

Each of these categories is carried out with the aim of certifying the sharia hotels in Indonesia, especially at the Surabaya Syariah Namira Hotel. Syariah Namira Hotel, based on observations, is still classified in the Hilāl-1 category. Hilāl-1 category is a category that still has leniency in sharia rules. In other words, this Hilāl-1 category, according to Article 1 point 5 of the Minister of Tourism and Creative Economy Regulation No. 2 of 2014, is a classification for sharia hotel business which is considered to meet all sharia hotel business criteria that are needed to serve the minimum needs of Muslim tourists.

Sharia hotel business criteria is the formulation of qualifications and/or classifications that cover aspects of products, services and management. In the classification of sharia hotels, there are two criteria, namely the absolute criteria and the absolute criteria in terms of product, service and management aspects. Absolute criteria are the minimum terms and conditions regarding products, services and management that must be met and implemented by hotel entrepreneurs so that they can be recognized as sharia hotel business and obtain sharia hotel business certification. The absolute criteria are provisions and requirements regarding products, services and management that can be implemented by sharia hotel entrepreneurs to meet the specific needs of Muslim tourists.

Absolute criteria that apply to the Hilāl-1 syariah hotel business are assessed including: product aspects consisting of 8 elements and 27 sub elements, service aspects consist of 6 elements and 20 sub elements and management aspects consist

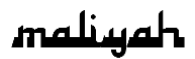


of 2 elements and 2 sub elements. The absolute criteria, that apply to sharia hotel businesses, do not affect the assessment in the sharia hotel business certification process and do not have an impact on the classification of sharia hotel businesses.

Absolute criteria that apply to the Hilāl-2 syariah hotel business are assessed including: product aspects consisting of 11 elements and 40 sub elements, the service aspect consists of 10 elements and 28 sub elements and management aspects consist of 3 elements and 6 sub elements. The absolute criteria, that apply to sharia hotel businesses, do not affect the assessment in the sharia hotel business certification process and do not have an impact on the classification of Sharia hotel businesses.

Based on the application of sharia principles applied by the Syariah Namira Syariah Hotel in accordance with the Minister of Tourism and Creative Economy Regulation No. 2 of 2014, the authors conclude that the Syariah Namira Hotel in Surabaya is a sharia hotel in the Hilāl-1 category.

The followings are the implementation of Sharia principles in the aspects of products, services and management at the Surabaya Syariah Namira Hotel:

1. Management. There are two elements and sub-elements of management that are determined as the criteria for the Hilāl-1 category sharia business enterprises and all of them have absolute criteria. The following implementation aspects of the management of the Syariah Namira Hotel Surabaya are: (a) Business Management. Based on the writer's observation, the elements of business management that have been set by the government are in accordance with the management of the Syariah Namira Hotel; (b) Human Resources. Based on these observations, the human resources element which only has one absolute sub element has been implemented by the Surabaya Syariah Namira Hotel. An obligation for a Muslim to cover genitalia in carrying out daily activities.

2. Product 
a. General Toliet. Based on the writer's observation, the elements of public toilet can be said to be fully met by the Syariah Namira Hotel. The deficiencies seen in the public toilet of the Syariah Namira Hotel are located in the absence of an insulator in the male urinal.

b. Guest bedroom. Based on the observations above, of the 4 sub elements in the guest bedroom, all of them are fulfilled by the Syariah Namira Hotel. Including the absolute sub-element in point 2 is also available in the guest bedroom of the Syariah Namira Hotel.

c. Guest bathroom. All sub elements are absolute criteria and all of them have been fulfilled by the Syariah Namira Hotel. The author adds that more sharia can be attached to prayer posts such as prayer in/out of the toilet, mirrored prayers or other prayers. Because it will be useful for guests to remember Allah better.

d. Kitchen. All kitchens or pantries at the Syariah Namira Hotel process halāl food and drinks. The hotel restaurant has been certified by the Indonesian Ulema Council of East Java Province (MUI-East Java). Al-Arush and Gahwaji Sky Lounge Restaurants have received halāl certificates from MUI-East Java so that they are guaranteed to be halāl from food and beverage ingredients, how to make them, place and serve food and drinks.

e. Employee room. The toilets in the employee room at Syariah Namira Hotel have 2 lockers, 1 for rooms and 1 for restrooms. When hotel employees want to worship, they perform ablution directly at the hotel Musholla (the place for prayer and smaller than Masjid). If there are employees who want to change clothes, they also use the toilet because the Syariah Namira Hotel does not have a special changing room. The staff room also has no divisions between men and women

f. Praying room. Syariah Namira Hotel has 1 prayer room on the 2nd floor and is always in a clean and wellmaintained condition. The hotel janitor is responsible for the Mosque. The prayer area for men and women is 
separated by a high board so that the view is maintained.

The author's observations, both the absolute criteria and the non-absolute criteria have been selected by the Syariah Namira Hotel as well as where the ablution is separated between men and women and the ablution disposal site is in good condition. As for the swimming pool, Syariah Namira Hotel does not have it but is still on-going process of constructing. That right is due to the Syariah Namira Hotel is still being classified as a 3 star and if it wants to make a swimming pool, it must also separate between men and women.

3. Service. There are several service elements that have been determined by the government. Of the 6 elements that have been designated as business classification of Hilāl-1, Syariah Namira Hotel has only 3 elements that are fulfilled. However, the failure to fulfill these 3 elements does not make the Syariah Namira Hotel deemed unfit as a sharia hotel business.

Here are some of the elements and sub-elements of the service at the Syariah Namira Hotel in Surabaya:

a. Front office. According to the author, the Syariah Namira Hotel meets all of these sub elements. Even though there are only 2 absolute elements in the front office criteria, the five sub-elements are available at Syariah Namira Hotel. It always selects guests, although they are not the absolute criteria in the Hilāl1 sharia hotel business. It is difficult for the hotel to find a married couple or not by referring to their resident identity card. Often the guest identity card has not been updated, so it still shows a different address. Meanwhile, if referring to a marriage certificate, in general, the voisitors are not willing and have no ned to bring it.

Seeing the above facts and referring to the spirit of sharia which tends to take convenience and leave things that are difficult without being accompanied by feelings to make it easy, guest selection can be done

\section{maliyath}


based on a strong suspicion. So that, if th guests who are in pairs are suspected not to be husband and wife, they must reject and vice versa. To be able to get a strong suspicion of a partner, a basic criterion for allegations can be made including: ${ }^{27}$ (a) Physical symptoms: (a) The couple looks awkward or very intimate; (b) Saying the word affection to their partner; (c) Distance when visiting the front office counter; (b) Performance: (a) Female couples in sexy clothes with excessive makeup; (b) Female couples in school uniforms or young/young students; (c) Do not bring overnight equipment (bags/luggage); (d) The age difference is quite striking. If in doubt and the indications tend not to be husband and wife, it is better for couples who will stay overnight to be rejected. But, if the indications show that the couple is husband and wife, they should be allowed to check in.

b. Housekeeping. Based on the author's observations, the absolute criteria for the housekeeping element has been fulfilled by the Syariah Namira Hotel in the form of providing clean and well-maintained prayer equipment. Similarly, the sub-elements of the provision of the mushaf, the hotel has provided it. One sub element that is not available in the hotel is the area/room for Friday prayer, because there is a Mosque near the hotel. The hotel added, to complete the housekeeping element, the hotel had installed a prayer time schedule at the hotel front office. The hotel also provides daily Muslim motivation through Islamic magazines available in the hotel lobby. Islamic magazines are also available in each guest room to fill visitors' free time.

c. Eat and drink. Based on the author's observation, both the absolute criteria and the non-absolute criteria on eating and drinking elements are all met by the Syariah

${ }^{27}$ Riyanto Sofyan, Bisnis Syari" ah Mengapa Tidak?, (Jakarta: Gramedia Pustaka Utama, 2011), 69-70. 
Namira Hotel. The hotel restaurant is open at all times, as well as in the month of Ramadan for travelers, women who are unable to fast and those who are elderly based on sharia by not reducing respect for those who fast.

d. Sports, recreation and fitness. There are no sports, recreation and fitness facilities available at the Syariah Namira Hotel in Surabaya

e. Spa (if available). There are no sports, recreation and fitness facilities available at the Namira Syari'ah Hotel in Surabaya.

f. Entertainment facilities. Based on the above observations, all sub elements are absolute criteria and all of them have been fulfilled by the Syariah Namira Hotel. Added by the hotel, non-muhrim guests who want to visit must meet in the lobby or outside the room. For this reason, hotel security will always monitor guests' activities through an installed CCTV camera. Television broadcasts in hotel rooms have been sorted, there are only local and Islamic broadcasts. The hotel has also given a security code on the television so that guests cannot change television broadcasts.

\section{Closing}

Based on the analysis of the above data, the authors conclude as follows:

First, the management and service the Surabaya Syariah Namira Hotel, including products and facilitis, have been implemented based on the concept of sharia principles. However, based on the regulation on Tourism and Creative Economy Number 2 of 2014, it is still in the process of adjusting to the existing regulations namely concerning Guidelines for sharia hotel business implementation.

Second, Eventhough, the implementation of Sharia principles have been applied in the Surabaya Syariah Namira Hotel, but it is still classified as the Hilāl-1 category according to the Regulation of the Minister of Tourism and Creative

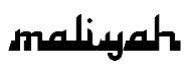


Management Of The Surabaya Syariah Namira Hotel ...

Economy of the Republic of Indonesia Number 2 of 2014 concerning Guidelines for Sharia Hotel Business Operation

\section{Bibliography}

Hafidhuddin, Didin Hafidhuddin, Hendri Tanjung, Manajemen Syariah dalam Praktik, Jakarta: Gema Insani Press, 2003. Janitra, M. Rayhan, Hotel Syariah Konsep dan Penerapan, Depok: Raja Grafindo Persada, 2003.

Keputusan Dirjen Pariwisata Nomor 14/U/II/1988.

Kotler, Phlip, Manajemen Pemasaran, Jakarta: PT. Gelora Aksara Pratama, 2009.

Lupiyadi, Rambat, Manajemen Pemasaran Jasa, Salemba: Jakarta, 2008.

Moenir, Maanajemen Pelayanan Umum di Indonesia, Jakarta: PT. Bumi Aksara, 2002.

Mujib, Abdul, "Analisis terhadap Konsep Syariah pada Industri

Perhotelan di Indonesia”, Jurnal Ilmu Syariah dan Hukum, Vol. 50. No. 2.

Mudhafier, Fadhlan, Makanan Halāl, Jakarta: Zakia Press, 2004. Nawar, Agus, Psikologi Pelayanan, Bandung: Alfabeta, 2002.

Saputri, Rizka, "Tinjauan Hukum Islam Tentang Praktek

Pengelolaan Hotel Syariah, Undergraduate thesis-UIN Raden Intan, Lampung, 2017.

Sofyan, Riyanto, Bisnis Syariah Mengapa Tidak? Jakarta:

Gramedia Pustaka Utama, 2011.

-------, Bisnis Syariah Mengapa Tidak? Penerapan pada Bisnis Hotel, (Jakarta: PT. Gramedia Pustaka, 2011.

Sutanto, Hotel Proprietors Act dalam Manajemen Penyelenggara Hotel, Jakarta: Salemba, 2005.

Sugianto, Hotel Front Office Administration, Administrasi Depan Office, Jakarta: Gramedia Pustaka Utama, 2000.

Tjiptono, Fandy, Service Manajemen: Mewujudkan Pelayanan Prima, Yogyakarta: ANDI, 2008.

https://www.booking.com/hotel/id/namira-syariah-

surabaya.id.html , 25 Januari 2018. 
http://surabaya.tribunnews.com/2017/07/30/andalkankonsep-syariah-hotel-namira-syariah-bidik-jemaah-danpengunjung-masjid-al-akbar, 25 Januari 2018.

Puspa, Interview, Surabaya 20 January 2018.

Rifa, Interview, Surabaya 21 January 2018.

Enny, Interview, Surabaya 21 January 2018

Mustofa Bawazieer, Interview, Surabaya 20 January 2018.

Khalda, Interview, Surabaya 20 January 2018. 